\title{
ANALYSIS OF STUDENTS' NERVOUS SYSTEM'S TYPOLOGICAL PROPERTIES, IN ASPECT OF RESPONSE TO EXTREME SITUATION, WITH THE HELP OF MULTI-DIMENSIONAL ANALYSIS
}

\author{
Kozina Z.L. ${ }^{1}$, Iermakov S.S. ${ }^{2}$ \\ ${ }^{1}$ H.S. Skovoroda Kharkiv National Pedagogical University \\ ${ }^{2}$ Kazimierz Wielki University in Bydgoszcz
}

\begin{abstract}
Purpose: determination of objective and subjective characteristics of students' with different properties of nervous system fear of heights. Material: In the research 10 students of 18-19 years old age, who did not practice sports, participated. The students fulfilled one exercises: passing suspended ferriage in hiking. This exercise gives subjective perception of height and creates artificial conditions for appearing of fear. He exercise was fulfilled under all required safety measures and supervised by experienced instructor. Cluster and discriminant analysis were used. Results: we have shown that is possible to divide people into groups by indicators of functional changes in extreme situation in combination with indicators of psycho-physiological potentials and properties of nervous system. We have found that the most significant indicators for distribution of students into groups by individual typological properties are speed and accuracy of passing of psycho-physiological tests with different modes of signals' supply as well as functional changes before exercise of extreme character. Conclusions: It was determined that students with strong type of nervous system had confidently less heart beats rate before fulfillment of extreme exercise than the students with weak type of nervous system. Subjective feeling of fear before fulfillment of extreme exercise was also confidently less in representatives of strong type of nervous system.
\end{abstract}

Key words: students, fear, analysis, cluster, discriminant.

\section{Introduction}

Modern world often require from person to act effectively in extreme situation $[21 ; 24 ; 28 ; 30 ; 33 ; 34]$. Yu.V. Scherbatykch [21] points at the fact that one of main obstacles for taking correct decisions and realization of effective actions is fear. Fear is accompanied by panic. It blocks adequate perceiving of situation and taking correct decisions for its overcoming [21]. With it, one can assume that people with different types of supreme nervous' functioning [9; 10; 11; $14 ; 15 ; 16 ; 17]$ respond to extreme situation differently. Understanding of peculiarities of extreme situations' perceiving by people with different types of supreme nervous functioning response to sudden extreme situations will help to work out the methods of fear's overcoming by people with different properties of nervous system. This problem is rather urgent for to-day's youth, with students as the most numerous category $[5 ; 6 ; 7 ; 8 ; 18 ; 19]$.

For solution of our tasks it was necessary to conduct researches with students' fulfillment of motor functioning, which can be considered extreme by subjective perceiving. But actually, such kinds of functioning shall not threaten life and health of students. One of such kinds of motor functioning is passing of suspended ferriage over raving of 5 meters depth in hiking [4]. Nowadays technology of this exercise's fulfillment envisages full safety for human life and health with active support of experienced instructor.

Thus, passing of suspended ferriage over raving is completely safe for human life and health. However, this exercise gives subjective perception of height and creates artificial conditions for fear's appearing. In this connection this kind of motor functioning can be used for studying of the mentioned problem.

The urgency of the present research is also connected with need in revelation of individual peculiarities of extreme situations' perceiving for creation of methods for fear's overcoming by students of different psycho-physiological types $[37 ; 38 ; 40 ; 41]$. Students' age is the most favorable period for development of ability to control emotions [25; 26; 29; $35 ; 36]$.

The problem of persons' with different typological properties of supreme nervous functioning response to fear has nearly not been researched. That is why the chosen direction of our researches is actual and urgent.

The hypothesis of the research is an assumption that people with different types of supreme nervous functioning perceive extreme situations differently. It can reflect in different subjective and objective indicators.

() Kozina Z.L., lermakov S.S., 2015

http://dx.doi.org/10.15561/20755279.2015.0302 


\section{Purpose, tasks of the work, material and methods}

The purpose of the research: is to determine objective and subjective characteristics of fear of heights' manifestation in students with different properties of nervous systems.

Material and methods: determination of individual typological peculiarities was conducted in convenient for every student time individually with the help of analysis of psycho-physiological indicators (time of simple and complex response to light irritators) in different modes of signal supply. Tests were conducted by program "Psycho-diagnostic" $[2 ; 12 ; 20]$. We registered time and quantity of mistakes in tests for simple and complex responses, indicators of strength and mobility of nervous processes, nervous processes by tests "Complex visual-motor response to signal supply with forced rhythm".

From physiological methods of research we used determination of heart beats rate (HBR) with the help of monitor of HBR continuous registration «Polar» before and after fulfillment of exercise for passing of suspended ferriage in hiking. With registration HBR before exercise students were in rest for 5-10 minutes for HBR stabilization. Then HBR was registered.

The received data (23 indicators) were processed by method of hierarchic cluster analysis and discriminant analysis with obtaining data for every separate case [3]. The received, as a result of multi-dimensional analysis, groups of students were compared between each other by all registered indicators. Besides, we conducted students' questioning for registration of their subjective feelings of fear by non-linear scale of Borg [1;27] before passing of suspended ferriage. In the research 10 students of 18-19 years old age, who did not practice sports, participated. All students fulfilled exercise "passing suspended ferriage" for the first time.

\section{Results of the research}

For determination of groups of students, who distinguish by individual typological features, different methods can be used [3]. For example, we can divide students into groups, having built Sigma scale by registered indicators. Then, it is necessary to choose the most significant indicator and divide students into groups by it. This method is suitable in case if there is present one the most significant indicators from all registered in research. In our case all registered indicators were significant for determination of students' individual features. In this connection it is necessary to analyze all complex of indicators. For this purpose method of multi-dimensional analysis is used: factorial, cluster, discriminant [3]. As far as in our research main task is connected with students' distribution into groups, we do not use factorial analysis. In our case the most informative for students' distribution into groups by properties of nervous system is cluster analysis.

Cluster analysis permits to receive groups of the tested as a result of generalization of all tests' results [3]. It conditions application of complex approach to revelation of individual features of the tested.

For substantiation of optimal quantity of clusters we used cluster coefficients, which reflect step-by-step process of students' combining into clusters. It is considered that key step of combining of the tested in clusters is the step of beginning of non-linear increasing of clustering coefficients [3]. In our case it is step 7 (see table 1). Exactly on seventh step increasing of cluster coefficient sharply exceeds values of its increasing on previous steps. On the next stage, for determination of clusters' optimal quantity it is necessary to deduct quantity of steps of smooth cluster coefficients' increasing from quantity of the tested [3]. In our case from 10 tested we deduct 7 steps; we receive 3 clusters.

Then, in order of combining in clusters (see table 1) and by dendogram of cluster analysis (see fig.1) we can determine belonging of every tested to cluster. At first step tested number 3 and 5 combined. At second stem number 4 joined to them (see table 1, fig.1). At third step tested number 7 and 1- combined with this cluster. At forth step tested No.1 joined (see table 1, fig.1). At fifth step second cluster started to form: tested number 2 and 8 combined (see table 1 and fig.1). At sixth step combining inside first cluster continued; tested 7 combined with tested 1 (see table 1, fig.1).

The sevenths step is rather special in process of students' combining in clusters: just from it non-linear increase of cluster coefficients starts. In this case the tested, joining at this and at further steps significantly differ from the previous by integral assessment of indicators. At this step tested number 6 combined. That is why he can be related both to the first cluster and to the second. On the other hand, it can be specified into third cluster. More over, optimal quantity of clusters, according to start of non-linear cluster coefficients' increase, is 3. On dendogram (fig.1) this tested is shown nearer to the first cluster.

At eighth step combining of second cluster continued: tested with conventional number 2 and 9 combined (see table 1, fig.1). At last step tested of two clusters combined. As we can see in table 1 and fig. 1 conventional distance 
(cluster coefficient) between integrated indicators of testing of these groups' members dozens times exceed previous cluster coefficients. From it, it is followed that combined at the last stage tested belong to different clusters.

Process of students' combining in clusters (groups) with the help of cluster analysis by values of heart beats rate (HBR) in situation of fear of heights' overcoming and by psycho-physiological indicators

\begin{tabular}{|c|c|c|c|}
\hline \multicolumn{2}{|c|}{ Cluster Combined 2 Clusters } & \multirow{2}{*}{ Coefficients } \\
\hline \multirow{2}{*}{ Stage } & Case № & Case № & \\
\cline { 2 - 4 } & 3 & 5 & 2339 \\
\hline 1 & 3 & 4 & 4738 \\
\hline 2 & 7 & 10 & 7774 \\
\hline 3 & 1 & 3 & 9234 \\
\hline 4 & 2 & 8 & 10767 \\
\hline 5 & 1 & 7 & 12775 \\
\hline 6 & 1 & 6 & 24137 \\
\hline 7 & 2 & 9 & 27064 \\
\hline 8 & 1 & 2 & 80628 \\
\hline
\end{tabular}

Thus, cluster analysis of testing indicators of 10 tested resulted in the following: students are divided into 2 groups (see table 2, fig.1). The first group includes students under conventional numbers 3,5,4,1,7,10 by degree of similarity of testing results (see table 2, fig.1); the second group includes students numbered 2,8,9 (see table 2, fig.1). Tested number 6 can form separate cluster, intermediate in respect to the first two ones. He can also be related both to the first and to the second clusters. According to dendogram he bends more to the first cluster (see fig.1).

Discriminant analysis permits to specify belonging of the tested to groups with producing of statistic for every case $[3 ; 27]$. With it, belonging of other tested to groups is unknown. In our research, when conducting discriminant analysis, we assumed that tested under numbers 3, 4 belonged to group 1 and tested 2 and 8 - to group 2 . To group 1 we related tested number 6 as well (see table 3).

Discriminant analysis confirmed belonging of tested 3, 4, 2 and 8 to the mentioned groups. Besides, the tested whose belonging to groups was not shown, were distributed by discriminant analysis analogous to results of cluster analysis. Exclusion was tested number 6: as a result of discriminant analysis he was characterized as "wrongly classified case" and related to group 2 with probability of 0.583 (see table 3 ). This value of probability (close to 0.50 ) reflects little preponderance (by 0.083 conv.un.) in favor of second group. 
Conventional scale of distances between indicators of every tested

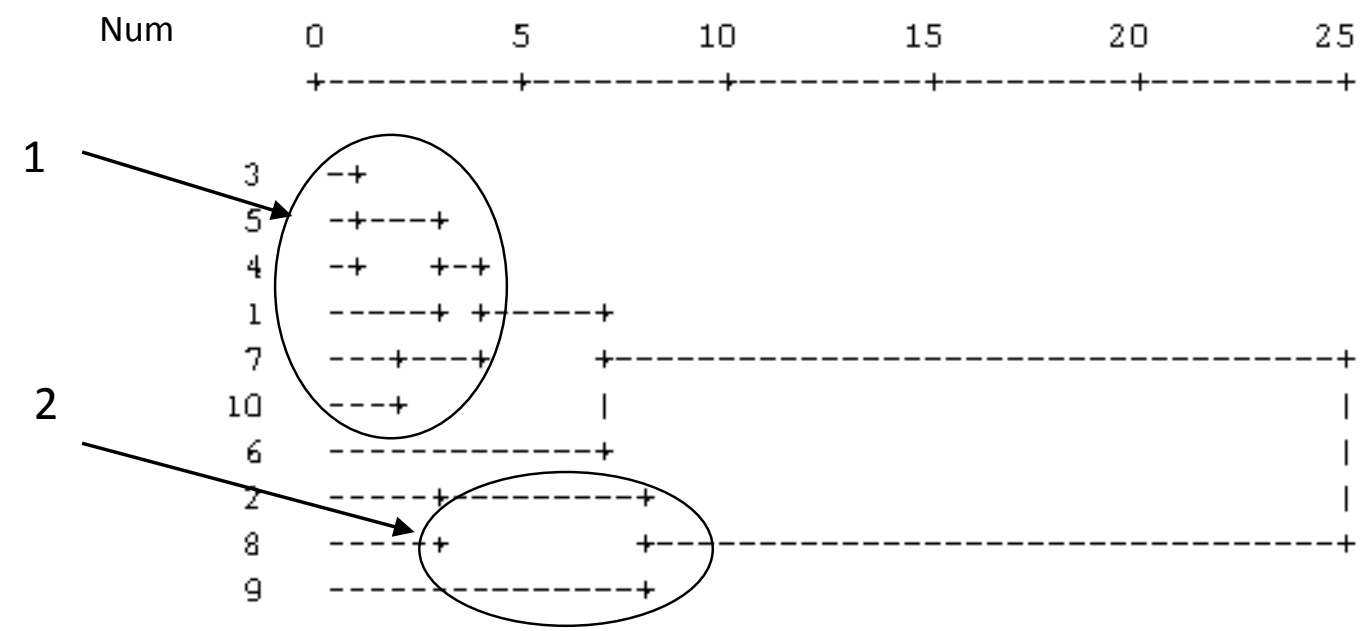

Fig. 1. Dendogram of cluster analysis of students' distribution into groups by heart beats rate (HBR) values in situation of fear of heights' overcoming and by psycho-physiological indicators:

Num (by vertical axis) -= conventional number of the tested;

Horizontal upper scale - standardized "scale of distances" between testing indicators of the tested;

1,2 - groups of the tested, formed as a result of cluster analysis.

Table 2

Students' belonging to clusters by heart beats rate (HBR) values in situation of fear of heights' overcoming and by psycho-physiological indicators

\begin{tabular}{|c|c|}
\hline Conventional number of the tested & Belonging to cluster \\
\hline 1 & 1 \\
\hline 2 & 2 \\
\hline 3 & 1 \\
\hline 4 & 1 \\
\hline 5 & 1 \\
\hline 6 & $1 * *$ \\
\hline 7 & 2 \\
\hline 8 & 2 \\
\hline 9 & 1 \\
\hline 10 & \\
\hline
\end{tabular}

Notes:** - belonging to other cluster is possible

Thus, cluster analysis resulted in students' distribution in two groups. Belonging to cluster was specified with discriminant analysis. 
Students' distribution into groups with discriminant analysis by heart beats rate (HBR) values in situation of fear of heights' overcoming and by psycho-physiological indicators

\begin{tabular}{|c|c|c|c|}
\hline \multirow{2}{*}{ Case № } & \multirow{2}{*}{ Actual Group } & \multicolumn{2}{|c|}{ Highest Group } \\
\cline { 3 - 4 } & & Predicted Group & P \\
\hline 1 & Ungrouped & 1 & 0,997 \\
\hline 2 & 2 & 1 & 0,935 \\
\hline 3 & 1 & 1 & 0,975 \\
\hline 4 & 1 & 1 & 0,841 \\
\hline 5 & Ungrouped & $2 * *$ & 0,635 \\
\hline 6 & 1 & 2 & 0,583 \\
\hline 7 & Ungrouped & 2 & 0,961 \\
\hline 8 & 2 & 2 & 0,920 \\
\hline 9 & Ungrouped & 1 & 0,752 \\
\hline 10 & Ungrouped & & \\
\hline
\end{tabular}

Notes:** - misclassifies case

For clarification of the question, which indicators influenced on formation of clusters most of all, we compared the received samples by all testing indicators with the help of non parametrical statistic's methods [3] (in connection with relatively small samples). We found out confident differences between groups by HBR indicator before passing of suspended ferriage: in first group this indicator was $68.50 \pm 16$. b.p.m. ${ }^{-1}$, in second $-86.50 \pm 5.45$ b.p.m. ${ }^{-1}$ ( $p=0.039$ ). Besides, confident differences were found between groups by psycho-physiological indicators. For example, time of complex visual-motor response in first group was $435.33 \pm 43.27 \mathrm{~m} . \mathrm{sec}$; in the second group - 559.00 \pm 31 . m.sec. $(\mathrm{p}=0.000)$. Also, quantity of mistakes in complex visual-motor response is less in first group, comparing with the second:11.7 \pm 1.60 in first group and $13.25 \pm 1.50$ in second $(\mathrm{p}=0.038)$.

We detected confident differences also in tests, which are specific for determination of nervous system's properties: "complex visual-motor response with feedback, time" (358.50 18.50 m.sec. in first group and $439.50 \pm 65.74$ m.se. in second group, $\mathrm{p}=0.018$ ); "complex visual-motor response with feedback, quantity of mistakes" $19.50 \pm 2.95$ in first group and $23.50 \pm 1.73$ in second, $\mathrm{p}=0,041$ ); "complex visual-motor response with feedback, minimal time of signal exposure" (320.00 $\pm 30.33 \mathrm{~m} . \mathrm{sec}$. in first group and $365.00 \pm 41.23 \mathrm{~m} . \mathrm{sec}$. in second, $\mathrm{p}=0.040)$; "complex visual-motor

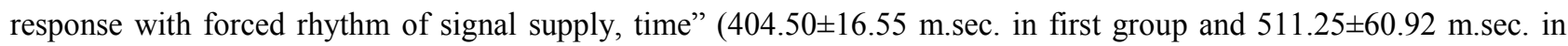
second group, $\mathrm{p}=0.000$ ). Besides, quantity of mistakes in complex visual motor response with forced rhythm of signal supply is confidently less in the first group than in the second at first, second, third and fifth stages $(p=0.009-0.037)$.

It is known $[14 ; 15 ; 16 ; 17]$, that in tests for complex visual0-motor response with feedback and with forced rhythm if signal supply quantity of mistakes indirectly characterizes power of nervous processes, while time of reaching of signal's minimal exposure in tests for complex visual-motor response with feedback - characterizes mobility of nervous processes. In our research quantity of mistakes and time of signal's minimal exposure are confidently less in the first group. This fact permits to conclude that first group consists of students with greater power and mobility of nervous processes in comparison with the second group. 
Basing on analysis of the received data, we named first group "and second - "participants with weak type of nervous system". It should be noted that in the first group (i.e. participants with strong and moderate type of nervous system) HBR was confidently less before passing of suspended ferriage. It witnesses that they are less anxious in comparison with participants with weak type of nervous system.

Subjective feeling of fear was registered by Borg's scale $[1 ; 23 ; 31]$. This scale was offered for registration of subjective feelings during fulfillment of physical wok [23]. Numerous researches showed informative character of subjective feelings and their high interconnection with physiological processes $[1 ; 13 ; 23 ; 31]$. That is why we applied Borg's scale for registration of students' subjective feelings of fear before passing of suspended ferriage. In group of students with strong nervous system mean value of feeling of fear was $0.51 \pm 0.05$ points (very-very weak, nearly not felt). In group of students with weak nervous system mean value of subjective feelings of fear was $4.06 \pm 1.08$ points $(p=0.000)$ (above middle). Thus, subjective feelings of fear were confidently higher in students with weak type of nervous system.

The received data of subjective feelings are comparable with heart beats rate values before fulfillment of exercise. Students with strong type of nervous system have confidently less HBR in comparison with representatives of weak nervous system's type.

\section{Discussion}

Our research closely overlaps with conception of fear as one of human emotion, which results from extreme situation. In psychology [21] it is considered that fear is negatively painted basic emotion. It is called basic as far as it can not be divided into components, but, at the same time, it can be the basis for other emotions.

Fear is sometimes called emotional process. It is not only manifested, it causes organism's reaction. Fear is transmitted to brain by neuro mediators. From there answer is supplied: which actions shall be undertaken in the situation [21].

Under influence of fear human organism starts to intensively excrete hormones. In skeletal muscles hormones facilitate emitting of energy. It happens for a person to be able either to defend against danger or to run away. It should also be noted that there are internal and external fear manifestations. External - is appearance of the person. Internal are physiological processes, which occur in organism [21].

Just, as a result of these processes fear is called negative emotion, because it influences on all organism. Besides, strong fear is considered to be toxic emotion, as far as it facilitates progressing of different diseases, including cancer, throat diseases, diabetes $[21 ; 32 ; 39 ; 42]$. That is why studying of individual features, manifesting in overcoming of extreme situations, is rather important task.

We conducted analysis of response to extreme situation of representatives with strong and weak types of nervous system. In this context is would be pertinently to conclude that definitions "strength" and "weakness" of nervous system are rather conventional at present. In opinion of modern researchers [15; 16], this indicator characterizes ability to perceive information per unit of time. Representatives of the so-called strong nervous system perceive less information per unit of time and that is why they are less sensitive to external and internal impacts. Hence, they are more resistant in respect to external and internal irritators. Representatives of the so called weak nervous system perceive more information per unit of time. They are more sensitive to external and internal irritators and get tired quicker. Thus, different people have different nervous system's mechanisms of adaptation to life. These mechanisms are equal by significance from the point of view of evolution and survival.

However, as our research illustrated, preparation from action in unknown situation is different for representatives of different nervous system's types. With the help of questioning we determined, that students with weaker strength and mobility of nervous processes spend more time to thinking over details of the fulfilled exercise; they try to clear up all difficult moments, maximally reduce to algorithms the process of complex exercise's fulfillment. Students with strong type of nervous system are more bent to take decisions directly in the process of exercise's fulfillment.

Thus, as a result of our researches we supplemented the data of G.V. Korobeynikov [14; 15], V.S. Lizogub [16], N.I. Makarenko [17] about presence of confident difference between representatives of strong and weak nervous system by psycho-physiological indicators.

It is purposeful to apply the received data when training specialists, whose work will be connected with danger for life as well as for physical education of students for their over coming fear in different life situations in the future. Полученные данные целесообразно применять при подготовке специалистов, работа которых связана с риском для жизни. Further working out of methodic of individual psychological training for extreme situations is of great 
practical significance. Such methodic shall envisage consideration of perceiving of extreme situation, specific features of life settings of people with different types of nervous system, understanding of different aspects of extreme situations' overcoming, safety measures and general state of mood.

The conducted research also showed that for distribution of the tested in groups by properties of nervous system and responses to extreme situation the most adequate are methods of multi-dimensional analysis $[3 ; 22 ; 27]$.

\section{Conclusions:}

1. We have shown that it is possible to divide people by indicators of functional changes in extreme situation together with psycho-physiological indicators and nervous system's properties into groups with the help of multidimensional analysis.

2. We have conducted analysis of subjective perceiving of extreme situation and functional changes in such situations of people with different types of nervous system on example of passing of suspended ferriage in hiking. We found out that there are confident differences between participants with strong and weak types of nervous system by HBR indicator before fulfillment of exercise, analogous to extreme situation (people with strong type of nervous system have confidently less HBR indicators than people with weak nervous system). Subjective feelings of fear also are confidently less in representatives of strong nervous system.

The prospects of further researches imply working out of methodic of fear's overcoming for people with different types of nervous system.

\section{Acknowledgement}

The authors acknowledge students, who participated in the researches and collection of experimental material. The research has been conducted in compliance with:

- "Combined plan of scientific research works in sphere of physical culture and sports for 2011-2015" by topic 2.4 "Theoretical-methodic principles of individualization in physical education and sports" (state registration number 0112U002001);

- Scientific-research work, financed by Ministry of education and science of Ukraine for 2013-2014 "theoretical-methodic principles of application of informational, pedagogic and medical-biological technologies for formation of healthy life style" (state registration number 0113U002003)

- Scientific-research work, financed by Ministry of education and science of Ukraine for 2015-2016 "Theoretical-methodic principles of application of informational, pedagogic, medical-biological orientation for motor and mental progress and formation of healthy life style" (state registration number 0113U002003).

\section{Conflict of interests}

The authors declare that there is no conflict of interest.

\section{References:}

1. Alekseev VM, Ruzhinskaia ZhL. Sub"ektivnaia i fiziologicheskaia ocenka napriazhennosti global'noj i regional'noj fizicheskoj nagruzki [Subjective and physiological assessment of tension of global and regional physical load]. Sbornik trudov uchenykh RGAFK 1998;4:148-151. (in Russian)

2. Kozina ZhL, Baribina LM, Korobiejnikov GV, Mishchenko DI, Cikunov OA, Kozin OV. Komp'iuterna programa «Psikhodiagnostika» [Computer program "Psycho-diagnostic"]. Patent UA, no. 39679; 2011. (in Ukrainian)

3. Biuiul' Akhim, Efel' Peter. SPSS: iskusstvo obrabotki informacii [SPSS: [Atr of processing of information], Sankt Petersburg: DiaSoftYuP; 2001. (in Russian)

4. Kozina ZhL, Kozin SV, Antonov OV, Grin' LV. Verevochnye parki kak sredstvo povysheniia dvigatel'noj aktivnosti uchashchejsia molodezhi [Rope Parks as mean of increasing of students' motor functioning]. Physical education of students 2011;6:40-45. (in Russian)

5. Iermakov SS. Informacionnye aspekty zdorov'ia i zdorovogo obraza zhizni v elektronnom nauchnom prostranstve [Informational aspects of health and healthy life style in electronic scientific space]. Valeologiia: suchasnij stan, napriamki ta perspektivi rozvitku [Valueology: modern status, directions and prospects of development]. 2006;2:59-65. (in Russian)

6. Iermakov SS. Informacionnoe obespechenie prepodavaniia lechebnoj fizicheskoj kul'tury v gumanitarnykh vuzakh [Informational provisioning of teaching of therapeutic physical culture in humanitarian HEEs]. 
Mezhdunarodnaia nauchno-metodicheskaia konferenciia "Rol' fizicheskoj kul'tury, sporta $i$ zdorov'ezberegaiushchikh tekhnologij v podgotovke specialistov”, Belgorod, BGTU [International scientificmethodic conference "Role of physical culture, sports and health related technologies in training of specialists", Belgorod, BSTU], 2006. p. 100-106. (in Russian)

7. Zajcev VP, Prusik Kristof, Iermakov SS. Fizicheskaia rekreaciia v strukture aktivnogo otdykha studentov [Physical recreation in structure of students' active leisure]. Physical education of students 2011;1:68-77. (in Russian)

8. Kashuba VA, Futornyj CM, Andreeva EV. Sovremennye podkhody k zdorov'esberezheniiu studentov v processe fizicheskogo vospitaniia [Modern approaches to students' health-preservation in process of physical education]. Physical education of students 2012;7:50-58. (in Russian)

9. Kozina ZhL. Analiz i obobshchenie rezul'tatov prakticheskoj realizacii koncepcii individual'nogo podkhoda $\mathrm{v}$ trenirovochnom processe $\mathrm{v}$ sportivnykh igrakh [Analysis and generalization of results of practical realization of individual approach conception in trainings of sport games]. Fizicheskoe vospitanie studentov tvorcheskikh special'nostej 2009;2:34-47. (in Russian)

10. Kozina ZhL. Nauchno-metodicheskie puti individualizacii uchebno-trenirovochnogo processa $\mathrm{v}$ sportivnykh igrakh [Scientific-methodic ways of individualization of training process in sport games]. In: Iermakov SS (editor) Problemy $i$ perspektivy razvitiia sportivnykh igr $i$ edinoborstv $v$ vysshikh uchebnykh zavedeniiakh [Problems and prospects of development of sport games and martial arts in higher educational establishments].]. Kharkov: KSADA; 2005:188-191. (in Russian)

11. Kozina ZhL. Sistema individualizacii podgotovki sportsmenov v igrovykh vidakh sporta [System of individualization of sportsmen's training in game kinds of sports], Lambret Academic Publishing Russia; 2011. (in Russian)

12. Kozina ZhL. Metodologicheskie osnovy vzaimointegracii nauchnykh znanij v oblasti fizicheskogo vospitaniia $\mathrm{i}$ sporta i smezhnykh nauk [Methodological principles of scientific knowledge inter-integration in field of physical education, sports and allied Sciences]. Physical education of students 2012;2:41-46. (in Russian)

13. Kozina ZhL. Vzaimosviaz' sub"ektivnykh i ob"ektivnykh parametrov fizicheskoj nagruzki v basketbole [Interconnection of subjective and objective parameters of physical load in basketball]. Pedagogics, psychology, medical-biological problems of physical training and sports 2000;7:43-46. (in Russian)

14. Korobejnikov GV, Koniaieva LD, Rossokha GV. Osoblivosti funkcional'nikh staniv nervovoi sistemi u sportsmenok - gandbolistok visokoi kvalifikacii [Peculiarities of nervous system's functional states in sportswomen - elite handball players]. Pedagogics, psychology, medical-biological problems of physical training and sports 2004;24:22-31. (in Ukrainian)

15. Korobejnikov GV. Psikhofiziologicheskie mekhanizmy umstvennoj deiatel'nosti cheloveka [Psychophysiological mechanisms of human mental functioning], Kiev; 2002. (in Russian)

16. Lizogub VS. Individual'ni psikhofiziologichni osoblivosti liudini ta profesijna diial'nist' [Human individual psycho-physiological features and professional functioning]. Fiziologichnij zhurnal 2010;56(1):148 - 151 . (in Ukrainian)

17. Makarenko NV. Metodika provedennia obstezhen' ta ocinki individual'nikh nejrodinamichnikh vlastivostej vishchoi nervovoi diial'nosti liudini [Methodic of examinations and assessment of individual neuro-dynamic properties of human supreme nervous functioning]. Fiziologichnij zhurnal 1999;45(4):125-131. (in Ukrainian)

18. Nosko MO, Iermakov SS, Garkusha SV. Teoretiko-metodichni aspekti zmicnennia fizichnogo zdorov'ia uchnivs'koi ta students'koi molodi [Theoretical and methodological aspects of strengthening physical health of pupils and students]. Visnik Chernigivs'kogo nacional'nogo pedagogichnogo universitetu 2010;76:243-247. (in Ukrainian)

19. Prusik Krzysztof, Prusik Katarzyna, Kozina ZhL, Iermakov SS. Features of physical development, physical preparedness and functional state of boys and girls - students of Polish higher educational establishments. Physical Education of Students 2013;1:54-61. doi:10.6084/m9.figshare.96415

20. Kozina ZhL, Barybina LN, Mishchenko DI, Kozin AV. Programma «Psikhodiagnostika» kak sredstvo opredeleniia psikhofiziologicheskikh osobennostej i funkcional'nogo sostoianiia $\mathrm{v}$ fizicheskom vospitanii studentov [Program "Psycho-diagnostic" as mean of determination of students' psycho-physiological 
characteristics and physical condition in physical education]. Physical education of students 2011;3:56-60. (in Russian)

21. Shcherbatykh IuV. Psikhologiia strakha [Psychology of fear], Moscow: Eksmo - Press; 2001. (in Russian)

22. Volodymyr Adashevsky, Sergii Iermakov, Krzystof Prusik, Katarzyna Prusik, Karol Gorner. Biomechanics: theory and practice. Gdansk: Zdrowie-Projekt; 2012.

23. Borg G. Psychophysical bases of percieved exertion. Medicine and Science in Sports and Exercise 1982;14:377381.

24. Chao-Chien Chen, Shih-Yen Lin. The impact of rope jumping exercise on physical fitness of visually impaired students. Research in Developmental Disabilities 2011;32(1):25-29.

25. Cieślicka M, Napierała M, Zukow W. State building somatic and motor abilities in kids practicing tennis on prebasic training. In: Hagner-Derengowska M, Zukow W. (red.) Health - the proper functioning of man in all spheres of life, School of Bydgoszcz, Bydgoszcz; 2012.

26. Cieślicka M, Napierała M. The somatic build of lightweight rowers. Medical and Biological Sciences 2009;23(3):33 - 38 .

27. Ivashchenko OV, Yermakova TS, Cieślicka M, Zukowska H. Discriminant analysis in classification of motor fitness of 9-11 forms' juniors. Journal of Physical Education and Sport 2015;15(2):238 - 244.

28. Forzoni R. 'Personal motivational videos: so where's the downside. The Sport and Exercise Scientist 2006;7:1011.

29. Frank Hookin Fu, Linxuan Guo, Yanpeng Zang. An overview of health fitness studies of Hong Kong residents from 2005 to 2011. Journal of Exercise Science \& Fitness 2012;10(2):45-63.

30. Gonzalez SP, Metzler JN, Newton M. The influence of simulated 'pep talk' on athlete inspiration, situational motivation, and emotion'. International Journal of Sports Science and Coaching 2011;6(3):445-459.

31. Kovářová Lenka, Pánek David, Kovář Karel, Hlinčík Zdeněk. Relationship between subjectively perceived exertion and objective loading in trained athletes and non-athletes. Journal of Physical Education and Sport 2015;15(2):186 - 193.

32. Loewenstein VR. Handbook of Sensor Physiology. Principles of Receptor Physiology. Berlin-Heidelberg-New York, Springer; 1992.

33. Loren L, Toussaint Mary O, Whipple Lana L, Abboud Ann Vincent, Dietlind L, Wahner-Roedler. A Mind-Body Technique for Symptoms Related to Fibromyalgia and Chronic Fatigue. EXPLORE: The Journal of Science and Healing 2012;8(2):92-98.

34. Mikael Bäckström, Mats Tinnsten, Andrey Koptyug, Lars-Erik Rännar, Peter Carlsson, Jonas Danvind, Håkan Wiklund. Sports Technology Education at Mid Sweden University. Procedia Engineering 2013;60:214-219.

35. Hribovska Iryna, Danylevych Myroslava, Ivanochko Victoria, Shchur Lydia. Organizational conditions of healthy lifestyle promotion for arts students. Journal of Physical Education and Sport 2015;15(2):218 - 224.

36. Paul R Medwell, Laura A Brooks, Barry S Medwell. Analysis of the Lawn Bowl Trajectory as a teaching tool for Sports Engineering: development of a graphical user-interface. Procedia Engineering 2011;13:531-537.

37. Paul R Medwell, Paul N Grimshaw, Will S Robertson, Richard M Kelso. Developing sports engineering education in Australia. Procedia Engineering 2012;34:260-265.

38. Prusik Katarzyna Iermakov SS, Kozina ZhL. Indexes of physical development, physical preparedness and functional state of polish students. Pedagogics, psychology, medical-biological problems of physical training and sports 2012;12:113-122.

39. Reginald Xi Wang. Self-determination and framing. An Interactionist Perspective on Self-Determination Theory: Place for Framing in AutonomySupport. New York University; 2013.

40. Shiloh S, Salton E, Sharabi D. Individual differences in rational and intuitive thinking styles as predictors of heuristic responses and framing effects. Personality and Individual Differences 2002;32:415-429.

41. Thomas AK, Millar PR. Reducing the framing effect in older and younger adults by encouraging analytic processing. The Journals of Gerontolog 2012;67(2):139-149.

42. Vargas TM, Short SE. Athletes' perceptions of the psychological emotional, and performance effects of coaches' pre-game speeches'. International Journal of Coaching Science 2011;5(1):27-43. 


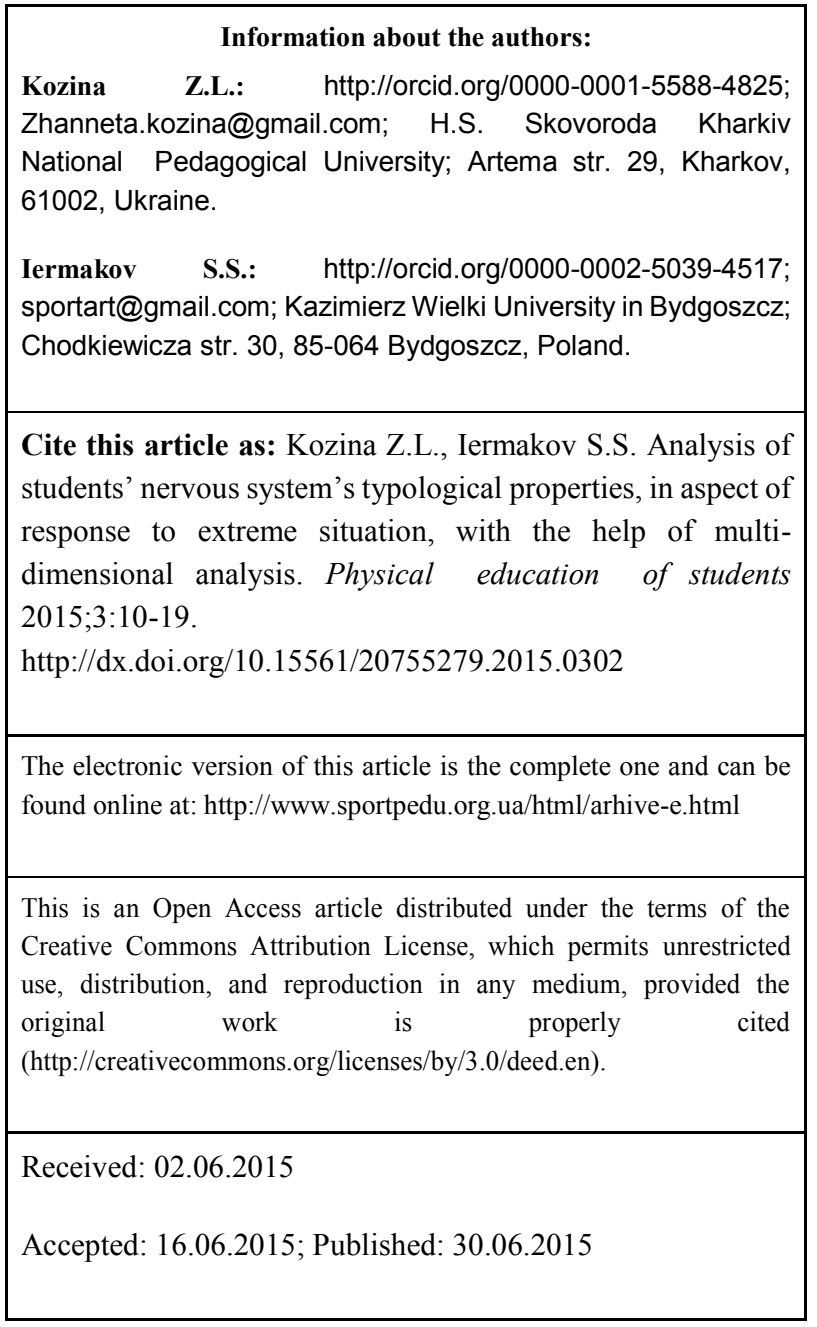

